\title{
Glacial dropstones: islands enhancing seafloor species richness of benthic megafauna in West Antarctic Peninsula fjords
}

\author{
A. F. Ziegler ${ }^{1, *}$, C. R. Smith $^{1}$, K. F. Edwards ${ }^{1}$, M. Vernet $^{2}$ \\ ${ }^{1}$ University of Hawai'i at Mānoa, Department of Oceanography, Honolulu, HI 96822, USA \\ ${ }^{2}$ Integrative Oceanographic Division, Scripps Institution of Oceanography, La Jolla, CA 92093, USA
}

ABSTRACT: The West Antarctic Peninsula (WAP) margin is dominated by glaciomarine fjords and has experienced rapid climate warming in recent decades. Glacial calving along the peninsula delivers icerafted debris (e.g. dropstones) to heavily sedimented fjord basins and the open continental shelf. Dropstones provide hard substrate, increase habitat heterogeneity, and may function as island habitats surrounded by mud. We used seafloor photographic transects to evaluate the distribution and community structure of Antarctic hard-substrate megafauna and the role of dropstones as island habitats in 3 WAP fjords and at 3 nearby shelf stations. Several lines of evidence indicate that dropstones function as island habitats; their communities adhere to principles of island biogeography theory with (1) a positive correlation between dropstone size and species richness, (2) an increase in the proportion of colonized dropstones with increasing dropstone size, and (3) a species-area scaling exponent consistent with island habitats measured globally. Previous work on the soft-sediment megafauna of this region found strong differences in community composition between fjord and shelf sites, whereas we found that dropstone communities differed within sites at small scales $(1 \mathrm{~km}$ and smaller). We identified 73 megafaunal morphotypes associated with dropstones, 29 of which were not previously documented in the soft-sediment megafauna. While dropstones constituted $<1 \%$ of the total seafloor area surveyed, they contributed $20 \%$ of the overall species richness of WAP megabenthos at depths of 437-724 m. WAP dropstone communities adhere to key principles of island biogeography theory, contribute environmental heterogeneity, and increase biodiversity in the WAP region.

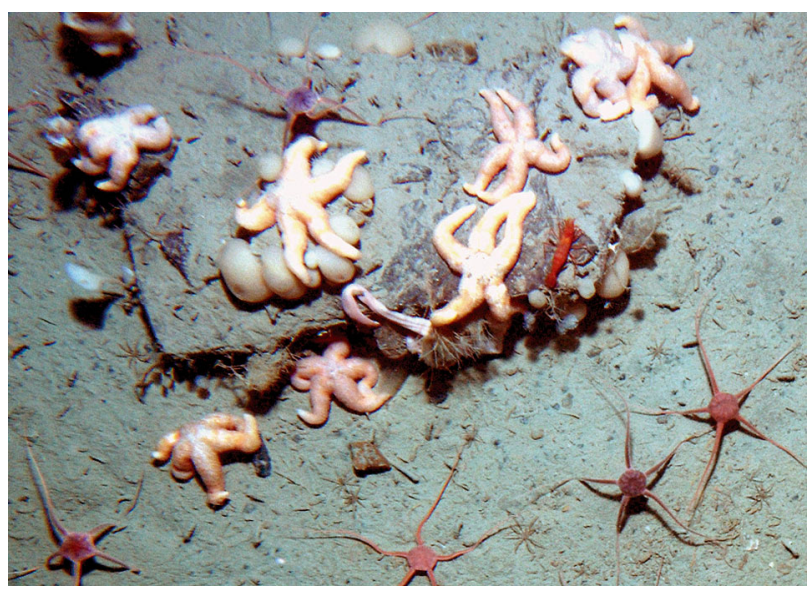

A rich community of megafauna inhabiting a glacial dropstone in Flandres Bay $(400 \mathrm{~m})$, a glaciomarine fjord on the West Antarctic Peninsula.

Photo: Dr. Craig R. Smith

KEY WORDS: Antarctica $\cdot$ Diversity $\cdot$ Heterogeneity · Dropstones $\cdot$ Fjord $\cdot$ Benthos

\section{INTRODUCTION}

The West Antarctic Peninsula (WAP) spans a transition between polar and subpolar climates and has experienced significant recent warming, i.e. a $6^{\circ} \mathrm{C}$ rise in mean winter air temperatures (Vaughan et al. 2001, Cook et al. 2005) and a $1^{\circ} \mathrm{C}$ increase in sea surface temperature since the 1950s (Vaughan et al. 2001, Cook et al. 2005, Meredith 2005). This warm-

() The authors 2017. Open Access under Creative Commons by Attribution Licence. Use, distribution and reproduction are unrestricted. Authors and original publication must be credited. 
ing, and changes in ocean circulation, have contributed to the retreat of $87 \%$ of glaciers along the WAP (Cook et al. 2005, 2016, Pritchard \& Vaughan 2007). Glaciomarine fjords (i.e. fjords with glaciers terminating in the ocean) dominate the WAP margin and are common in other polar regions. In Arctic glaciomarine fjords, e.g. on Baffin Island and Svalbard, plumes of fine-grained terrigenous sediments from tidewater glaciers cause burial disturbance, reducing the abundance, biomass, and functional diversity of macrobenthos (Wlodarska-Kowalczuk et al. 2005). Sedimentation rates within WAP fjords, measured on $100 \mathrm{yr}$ time scales, appear to be 1-7 mm yr ${ }^{-1}$ (Domack \& Ishman 1993, Domack \& McClennen 1996, Boldt et al. 2013) and are approximately an order of magnitude lower than estimated for inner Svalbard fjords over similar time scales (Elverhoi \& Seland 1983). Low rates of burial disturbance in WAP fjords allows an unexpectedly high diversity and abundance of megabenthos close to glacial termini (Grange \& Smith 2013). In addition, lower turbidity from glacial outflow compared to Arctic fjords may result in higher primary production and detrital food availability, increasing benthic abundance and diversity via pelagic-benthic coupling (Smith et al. 2006, 2012, Grange \& Smith 2013). These fjords are considered 'biodiversity hotspots' since they contain 3-38 times greater benthic megafaunal abundances than the adjacent continental shelf at similar depths and add substantially to the regional species pool (Grange \& Smith 2013). While soft-sediment megafaunal communities in WAP fjords have recently been assessed (Grange \& Smith 2013), hard-substrate communities in these fjords remain unexplored.

Subpolar conditions in the northern WAP favor glacier calving, delivering ice-rafted sediments to the seafloor, including dropstones (Domack \& Ishman 1993, Syvitski et al. 1996). Dropstones are ice-rafted debris in the pebble to boulder size range, i.e. $>2 \mathrm{~mm}$ diameter (Wentworth 1922, Bennett et al. 1996). Icebergs can have highly variable residence times within high-latitude fjords, ranging from 1 to $>12 \mathrm{mo}$ (Syvitski et al. 1996, Sutherland et al. 2014), suggesting a stochastic deposition of dropstones as icebergs drift through fjords and across the continental shelf. The addition of hard substrata, in the form of dropstones, to soft-sediment dominated benthic landscapes at fjord and shelf floors enhances habitat heterogeneity, potentially influencing biodiversity. Habitat heterogeneity has been shown to increase diversity in many ecosystems, ranging from forests to abyssal plains (MacArthur \& Wilson 1967, Simberloff
1974, Huston 1979, McClintock et al. 2005, Schönberg \& Fromont 2012, Amon et al. 2016), but the contribution of glacial debris to habitat heterogeneity has been assessed at only a few locations on continental shelves (Oschmann 1990, Starmans et al. 1999, Schulz et al. 2010, Meyer et al. 2015, 2016, Lacharite \& Metaxas 2017). On the Antarctic shelf, the most influential factors affecting benthic biodiversity are postulated to be disturbance (e.g. iceberg scour, burial from glacial sedimentation), sea-ice duration, productivity, and habitat heterogeneity (Gutt 2001, Gutt \& Piepenburg 2003, Cummings et al. 2006, Thrush et al. 2010). In Svalbard fjords and in the Weddell Sea, heterogeneity provided by dropstones enhances functional and taxonomic diversity (Meyer et al. 2015, Post et al. 2017), and similar patterns may exist for other soft-sediment habitats containing dropstones, including within Antarctic glaciomarine fjords.

A stochastic delivery of dropstones to the seafloor implies a heterogeneous distribution of fragmented hard substrata, forming island habitats. When considering the scale of single dropstones, the theory of island biogeography suggests that the species diversity on dropstones, if they function as habitat islands, will depend on the rates of faunal colonization and local mortality (MacArthur \& Wilson 1967, Rosenzweig 1995). Due to small island size and low dispersal abilities of most megabenthos, recruitment of megabenthos to dropstones is likely to be predominantly non-local (i.e. little self-recruitment). Therefore, the balance between colonization and mortality will control local population dynamics on individual islands, while colonization and extinction rates will define the dynamics of the entire metapopulation. For obligate hard-substrate fauna, community structure on an island will further be constrained by island size (which limits colonization rates and maximum population sizes) and the distance between neighboring islands (which limits dispersal rates) (MacArthur \& Wilson 1967, Rosenzweig 1995). The balance of these processes leads to different dynamic equilibria on islands of varying size and/or distance to source populations (Rosenzweig 2003). Application of island biogeography theory to WAP fjord dropstones predicts a positive relationship between dropstone size and species richness for obligate hard-substrate fauna. The absence of such a relationship might indicate the influence of additional abiotic factors such as sedimentation disturbance or dispersal limitation from isolating circulation features. Characteristics of the environment, such as the magnitude of overlying productivity which controls the flux of organic matter 
to the seafloor, may influence the community structure and especially the functional diversity of the communities between sites. The extent to which dropstone communities function as habitat islands has recently been investigated in Svalbard fjords (Meyer et al. 2016) but remains unassessed in most glaciomarine fjords, including along the WAP, which harbors novel patterns of biodiversity and community structure. While a positive correlation was found between dropstone size and species richness in Svalbard fjords, the mechanisms behind this island-like phenomenon are likely to be related to dispersal and not the same mechanisms that produce these patterns in terrestrial island communities, such as disturbance and competition (Meyer et al. 2016).

In this study, we quantified the distribution and megafaunal community structure of dropstones in 3 fjords and at 3 open-shelf stations along the WAP. With these data, we tested the predictions of island biogeography theory, explored the influence of various abiotic factors on dropstone community structure, and evaluated the contribution of dropstone assemblages to regional diversity along the deep WAP continental shelf. We found support for several predictions of island biogeography theory, and that dropstones provide an important habitat for a variety of megafaunal species, including many morphotypes that were not detected in diversity assessments of soft-sediment habitats in WAP fjords.

\section{MATERIALS AND METHODS}

\section{Study sites and data collection}

Digital still images of the seafloor were collected in 2010 during LARISSA Project cruise NBP10-01 aboard the RVIB 'Nathaniel B. Palmer' in 3 glaciomarine fjords along the WAP: Andvord, Barilari, and Flandres Bays. Additional images were obtained during FOODBANCS2 Project cruises LMG08-08 and LMG09-02 at the 3 shelf sites (referred to as stations $\mathrm{B}, \mathrm{E}$, and F) aboard the ASRV 'Laurence M. Gould' in 2008 and 2009 (Fig. 1). All fjord-basin and shelf stations fell within depths of 436-725 m (Table S1 in the Supplement at www.int-res.com/articles/suppl/m583 p001_supp.pdf). Seafloor images in phototransects were collected using the 'yo-yo camera' system with methods detailed by Grange \& Smith (2013). At each site (fjord basin or shelf station), 2 randomized $1 \mathrm{~km}$ phototransects were conducted (except in Outer Barilari Bay, where weather and sea-ice conditions allowed only 1 transect). Fjord transects were con- ducted within sediment-floored basins in the inner, middle, outer, and/or mouth of fjords (Fig. 1). Each phototransect produced approximately 100 images, from which 50 images of high quality were randomly selected for analysis. The images in this study were selected, color-corrected, and analyzed for softsediment fauna reported by Grange \& Smith (2013); we reanalyzed the same images for dropstones and associated fauna. Environmental data were also collected on each cruise. Bottom-water temperatures were extracted from CTD casts deeper than $350 \mathrm{~m}$, and all were conducted within $5.5 \mathrm{~km}$ and $36 \mathrm{~h}$ of phototransects.

To relate the variability in community composition between dropstones, sites, and habitats to the variability in the surrounding abiotic environment, we assessed a range of environmental parameters at our study sites (Table S2 in the Supplement). Where possible, environmental data were paired with phototransects by time of collection such that a single bottom-water temperature record corresponded to a single phototransect. Annual primary production (mg $\mathrm{C} \mathrm{m}^{-2} \mathrm{yr}^{-1}$ ) was derived from concentrations of silicic acid and nitrate in surface waters above the pycnocline. We assumed that winter nutrient concentrations above the pycnocline were representative of the nutrient concentrations at the start of the summer phytoplankton growth season. Annual production was calculated based on conversion of these nutrients to biomass, assuming no additional nutrient input during the summer growth season, which is a reasonable assumption given the stratification observed during summer months. Therefore, the annual production values presented here are conservative and could underestimate the true production in the fjords. To obtain better estimates of production within a fjord basin, we averaged production estimates derived from multiple nutrient measurements in each fjord. This is appropriate because water-column mixing integrates primary production at the scale of fjord basins, or larger (M. Vernet et al. unpubl. data).

\section{Dropstone and megafauna analyses}

In this study, 'dropstone' refers to rocks that were visible at the seafloor and were $\geq 3 \mathrm{~cm}$ in 2 minimum dimensions normal to one another. Dropstones and megafauna (animals $>1 \mathrm{~cm}$ in largest dimension) were counted within a clear and well illuminated $1.8 \mathrm{~m}^{2}$ area in the center of each selected image. In total, 1430 seafloor images were analyzed for dropstones and their associated megafauna. Megafauna 

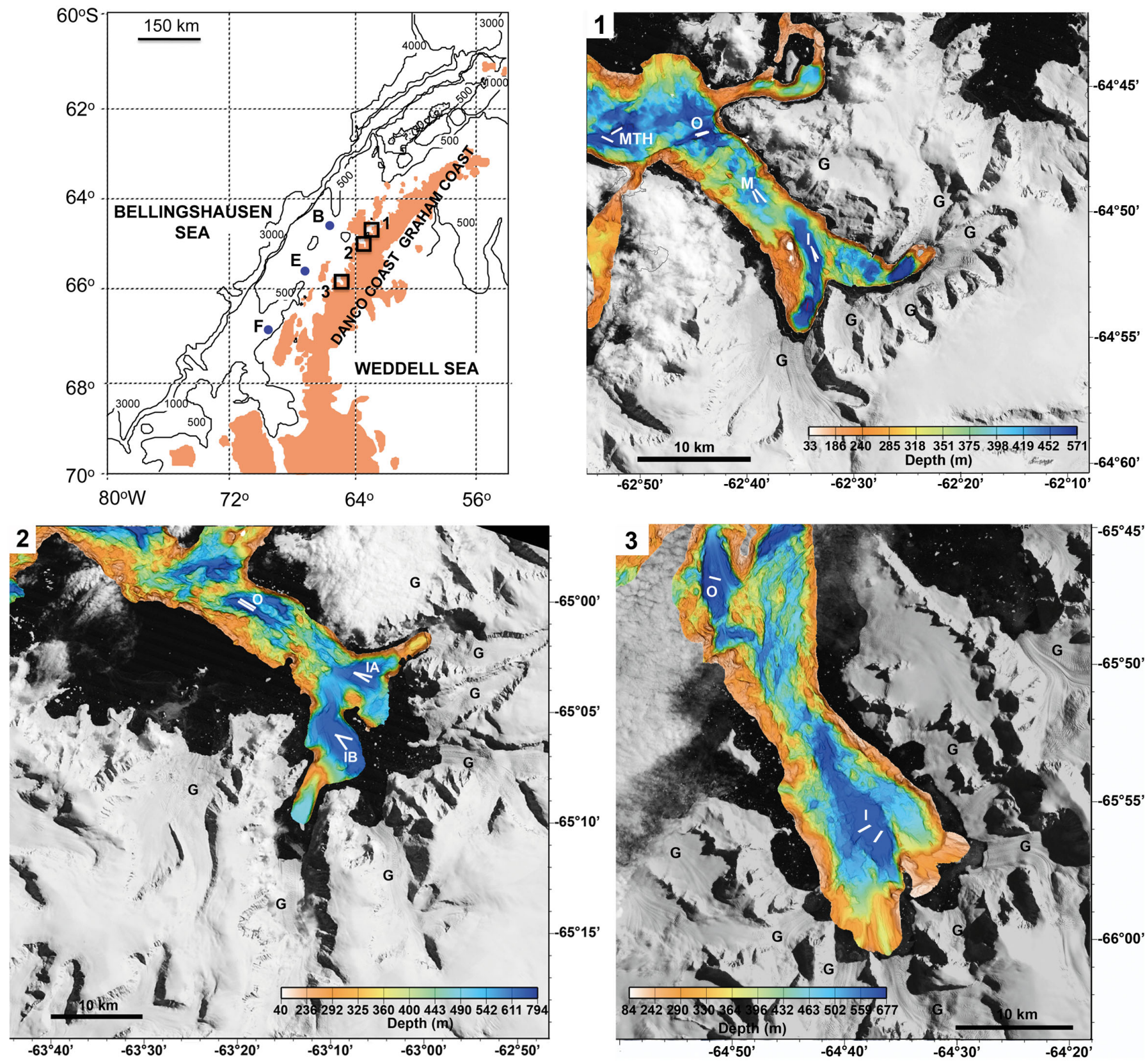

Fig. 1. Study area along the West Antarctic Peninsula. Bathymetry and glacial satellite imagery overlaid for (1) Andvord Bay, (2) Flandres Bay, and (3) Barilari Bay. White lines show phototransects in fjord basins; I: inner, M: middle, O: outer, MTH: mouth. G denotes major tidewater glaciers entering the fjords. B, E, and F correspond to shelf sampling stations (Grange \& Smith 2013)

were grouped into morphotypes, i.e. putative species, based on Grange \& Smith (2013), identification literature (Brueggeman et al. 1998), and feedback from taxonomists. Each morphotype represents the lowest level of identification possible within images and is therefore probably a minimum estimate of true taxonomic diversity. Megafaunal functional groups were assigned as per Grange \& Smith (2013) and included surface deposit feeders, suspension feeders, and predators/scavengers. Dropstones were manually outlined to measure total plan area (i.e. the topdown area of the dropstone surface), and the plan area of each stone covered by sediment, using Image ${ }^{\circledR}$. These measurements also provided calculations of dropstone density and the percentage of exposed hard substrate within each image. 


\section{Statistical analyses}

The Kolmogorov-Smirnov test was used to determine whether the size-frequency distributions differed between 2 groups; colonized and uncolonized dropstones. Mann-Whitney tests were conducted after significant Kolmogorov-Smirnov tests for pairwise comparisons of dropstone parameters (e.g. area and sediment cover) between the 2 groups. Kruskal-Wallis tests were used to test for between-site differences in plan area, percent of exposed hard substrate, and dropstone density. Pairwise comparisons of these parameters between habitat groups (e.g. fjord vs. shelf) were conducted using $t$-tests. To avoid Type II error and over-testing, only differences between the 2 habitat groupings (fjord and shelf) were conducted for a total of only $3 t$-tests. To further assess the contribution of various abiotic parameters to the total variation in megafaunal abundance and species richness, generalized linear mixed models (GLMMs) were created and compared using the 'glmer' function in the R package lme4 (Bates et al. 2015). GLMMs allow simultaneous testing of the role of predictors that vary at different scales: area and sediment cover vary at the dropstone scale, while density and percentage of hard substrate vary at the frame scale. Random effects for dropstone frame, transect, and/or site were included. These terms account for the hierarchical spatial structure of the data and quantify which spatial scales hold the greatest variation in megafaunal abundance and species richness. Additionally, a 'habitat' fixed effect was included, which accounted for whether observations originated from a fjord or the open shelf. A full model with all fixed and random effects contained too many parameters to be fit by the observational data available; therefore, some random effects were sequentially removed. Versions of the GLMMs with different random effects were assessed by comparing Akaike's information criterion (AIC) as well as the random-effects estimates themselves. Effects that equaled zero were eliminated first, and AIC comparisons determined which near-zero effects did not significantly improve model fit and could therefore be removed. The final model for megafaunal abundance included random effects for dropstone and transect, while the model for species richness included a random effect for site. Both models included a fixed effect accounting for the different habitats in which these dropstones occurred, i.e. fjord or shelf. Additionally, a binomial GLMM was created to explore the relationship between dropstone colonization (presence/absence) and dropstone sediment cover.
Patterns of community composition were explored through non-metric multidimensional scaling (nMDS) and Bray-Curtis similarity analyses using PRIMER ${ }^{\circledR}$ v6, as well as a canonical analysis of principal coordinates (CAP) using the 'capscale' function in the $\mathrm{R}$ package 'vegan' (Oksanen et al. 2017). nMDS analysis used square-root transformed abundance data pooled at the transect level for fjord sites. The squareroot transformation reduces the range of abundances so that species with abnormally high abundances do not drive community patterns. The number of individuals observed per transect at shelf sites was much lower than within the fjords, so shelf abundances of megafauna were pooled by site to provide similar numbers of individuals to fjord transects. CAP analysis related community composition at the transect level to dropstone parameters and abiotic factors in the fjords. Dropstone measurements used are thus transect means. The total variability in community composition that could be attributed to each parameter alone was determined using the 'adonis' function in R. This is a multivariate permutation test similar to PERMANOVA with permutations constrained within each sampling site. Finally, Chao 1 species-richness and rarefaction estimates were calculated using PRIMER ${ }^{\circledR} \mathrm{V} 6$ for fjord and shelf habitats, both individually and pooled, to determine the contribution of dropstones and fjord ecosystems to WAP regional $(\gamma)$ diversity.

\section{RESULTS}

\section{Dropstone size-frequency distribution}

In total, we measured 2972 dropstones, of which 467 were colonized by at least 1 megafaunal individual, and a total of 1766 individual megafauna were counted and identified. Dropstone plan area ranged from 4.6 to $4936.9 \mathrm{~cm}^{2}$, with an overall mean $\pm \mathrm{SE}$ of $67.0 \pm 3.9 \mathrm{~cm}^{2}$ (Table 1). The distribution of dropstone area was highly right-skewed, with $95 \%$ of dropstones $<250 \mathrm{~cm}^{2}$ and a few outliers $>2000 \mathrm{~cm}^{2}$ (maximum size $=4936.9 \mathrm{~cm}^{2}$ ). Mean dropstone area varied significantly by site (Kruskal-Wallis $\chi^{2}=91.108, \mathrm{p}<$ 0.001 ), although size did not vary significantly between fjord and shelf habitats ( $t$-test, $p>0.05)$. Shelf Stn B had significantly smaller dropstones than any other site confirmed by non-overlapping $95 \%$ confidence intervals (Fig. S1 in the Supplement). The percentage of seafloor area comprising exposed hard substrate differed by site (Kruskal-Wallis $\chi^{2}=191.95$, $\mathrm{p}<0.001)$ but, again, differences did not simply 
Table 1. Summary of dropstone measurements by sampling location. Mean area: average dropstone plan area, mean sediment cover: average percentage cover of dropstone area by sediment, dropstone density: total number of dropstones per seafloor area, hard substrate area: total percentage of seafloor area that is exposed hard substrate, abundance: number of megafauna per seafloor area, species richness: total number of species

\begin{tabular}{|c|c|c|c|c|c|c|c|c|c|}
\hline & $\begin{array}{l}\text { Frames } \\
\text { analyzed }\end{array}$ & $\begin{array}{c}\text { Mean } \pm \mathrm{SE} \\
\text { area } \\
\left(\mathrm{cm}^{2}\right)\end{array}$ & $\begin{array}{c}\text { Mean } \pm \mathrm{SE} \\
\text { sediment cover } \\
(\%)\end{array}$ & $\begin{array}{c}\text { Total } \\
\text { dropstones }\end{array}$ & $\begin{array}{l}\text { Dropstone } \\
\text { density } \\
\left(\mathrm{m}^{-2}\right)\end{array}$ & $\begin{array}{c}\text { Hard } \\
\text { substrate } \\
(\% \text { area })\end{array}$ & $\begin{array}{c}\text { Total } \\
\text { individuals } \\
\text { (n) }\end{array}$ & $\begin{array}{c}\text { Abundance } \\
\left(\mathrm{m}^{-2}\right)\end{array}$ & $\begin{array}{c}\text { Species } \\
\text { richness }(S)\end{array}$ \\
\hline \multicolumn{10}{|l|}{ Fjord } \\
\hline Andvord & 399 & $48.1 \pm 4.4$ & $66.1 \pm 1.4$ & 1502 & 2.09 & 0.34 & 1170 & 1.63 & 40 \\
\hline Inner & 99 & $45.9 \pm 7.1$ & $61.4 \pm 2.7$ & 366 & 2.05 & 0.33 & 75 & 0.42 & 17 \\
\hline Middle & 100 & $46.9 \pm 9.3$ & $68.0 \pm 2.8$ & 776 & 4.31 & 0.61 & 954 & 5.3 & 27 \\
\hline Outer & 100 & $66.8 \pm 13.2$ & $64.9 \pm 2.9$ & 101 & 0.56 & 0.19 & 71 & 0.39 & 18 \\
\hline Mouth & 100 & $47.4 \pm 6.4$ & $67.4 \pm 2.9$ & 259 & 1.44 & 0.23 & 70 & 0.39 & 20 \\
\hline Flandres & 295 & $94.3 \pm 17.8$ & $56.6 \pm 1.8$ & 1096 & 2.06 & 0.48 & 440 & 0.83 & 47 \\
\hline InnerA & 100 & $108.8 \pm 36.3$ & $63.6 \pm 2.6$ & 224 & 1.24 & 0.28 & 132 & 0.73 & 16 \\
\hline InnerB & 96 & $87.2 \pm 29.9$ & $55.4 \pm 3.3$ & 825 & 4.77 & 0.99 & 264 & 1.53 & 38 \\
\hline Outer & 99 & $150.6 \pm 20.6$ & $44.8 \pm 3.3$ & 47 & 0.26 & 0.19 & 44 & 0.25 & 6 \\
\hline Barilari & 150 & $46.4 \pm 4.1$ & $77.2 \pm 2.1$ & 173 & 0.64 & 0.06 & 40 & 0.15 & 12 \\
\hline Inner & 100 & $45.2 \pm 5.4$ & $78.1 \pm 2.5$ & 131 & 0.73 & 0.07 & 29 & 0.16 & 8 \\
\hline Outer & 50 & $50.0 \pm 4.7$ & $74.3 \pm 3.9$ & 42 & 0.47 & 0.05 & 11 & 0.12 & 7 \\
\hline \multicolumn{10}{|l|}{ Shelf } \\
\hline Stn B & 200 & $25.9 \pm 0.8$ & $85.8 \pm 1.7$ & 44 & 0.12 & 0.01 & 12 & 0.03 & 7 \\
\hline Stn E & 198 & $73.5 \pm 6.3$ & $64.9 \pm 2.2$ & 21 & 0.06 & 0.02 & 20 & 0.06 & 8 \\
\hline Stn F & 188 & $93.2 \pm 26.5$ & $57.3 \pm 1.8$ & 136 & 0.40 & 0.14 & 84 & 0.25 & 25 \\
\hline
\end{tabular}

represent a fjord-shelf distinction (t-test, $\mathrm{p}>0.05)$. The total seafloor area occupied by dropstones was only $0.77 \%$ of the entire surveyed area $\left(2574 \mathrm{~m}^{2}\right)$. Dropstone density was significantly higher within fjords compared to the open shelf ( $t$-test, $\mathrm{p}=0.013$ ), with maximum fjord densities 70 -fold greater than minimum shelf densities (Table 1). The proportion of dropstones colonized by megafauna increased with increasing dropstone size (Fig. 2). The size-frequency distributions of colonized and uncolonized dropstones differed significantly (Kolmogorov-Smirnov test, $D=0.50, \mathrm{p}<0.001$ ), with colonized dropstones

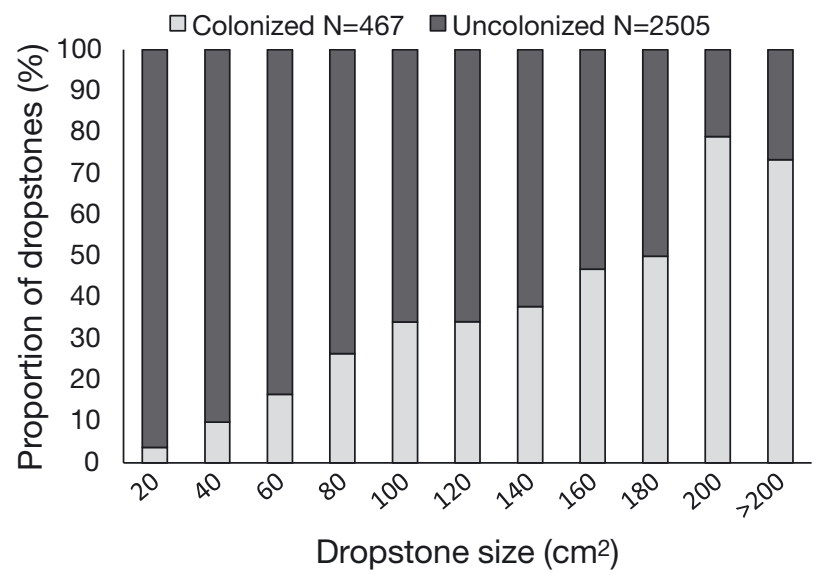

Fig. 2. Proportion of all dropstones that were colonized by at least 1 individual (light grey), and uncolonized dropstones (dark grey) binned by dropstone plan area. $\mathrm{N}$ indicates total observations having larger median size (Mann-Whitney $\mathrm{p}<0.001$ ) and significantly higher sediment cover (MannWhitney $\mathrm{p}<0.001$ ) than uncolonized dropstones.

\section{Dropstone megafauna}

In total, we observed 73 megafaunal morphotypes within 10 phyla on dropstones (Table S3 in the Supplement). The most diverse phylum was Porifera, followed by Chordata (mostly tunicates), Echinodermata, and Cnidaria. Examples of morphotypes and dropstone assemblages are shown in Fig. 3. Of the 73 morphotypes, $28(38 \%)$ were sessile and occurred only on hard substrates (called obligate hard-substrate fauna here), and of those, $66 \%$ were suspension feeders. The remaining 45 morphotypes were mobile deposit feeders and predators/scavengers that may use the dropstones opportunistically. Twenty-seven morphotypes were present at both fjord and shelf sites, while 9 morphotypes were unique to the shelf stations and 37 were unique to the fjords. Considering only obligate hard-substrate fauna, 15 morphotypes were common to both fjord and shelf stations, 11 were unique to the fjords, and 1 was unique to the shelf stations. Rank abundance revealed the dominance of a single morphotype, Bryozoan sp. 5, especially within the middle basin of Andvord Bay (Table S4 in the Supplement), which was more than 8 times more abundant than the second most abundant morphotype overall. However, 

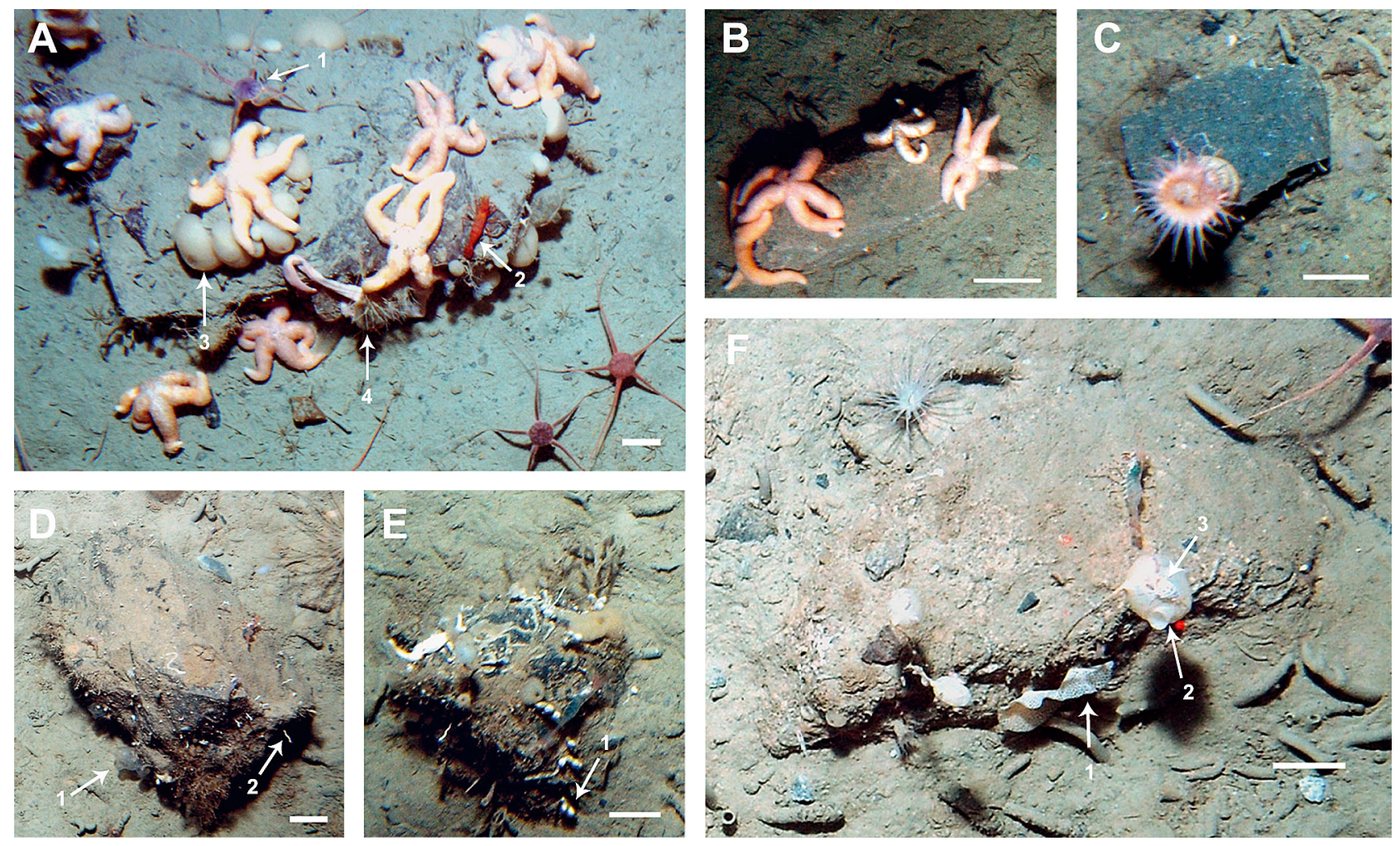

Fig. 3. Examples of dropstone megafaunal communities from different sites: (A,D) Flandres Bay and (B,C,E,F) Andvord Bay. All scale bars $=5 \mathrm{~cm}$. In panel A: (1) Ophionotus victoriae, (2) Notocrangon antarcticus, (3) Porifera sp. 3, (4) Bryozoan sp. 1 (Cellaria sp.). Panels B and C show Diplasterias brucei and Anemone sp. 1, respectively. In panel D: (1) Tunicate sp. 2 and (2) Bryozoan sp. 5. Panel E shows (1) Scalpelliformes sp. 1, and panel F shows (1) Reteporella sp. 1, (2) Pyura bouvetensis, and (3) Amphipod sp. 1 (eusirid)

species accumulation curves show that fjord and shelf sites remain under-sampled since they do not reach an asymptote (Fig. S2 in the Supplement), indicating that the number of unique morphotypes within fjord and shelf habitats may be overestimated.

\section{Modeling megafaunal abundance and species richness on dropstones}

The GLMM for megafaunal abundance indicated a significant effect only for dropstone area $(p<0.001)$, and non-significant effects for dropstone sediment cover, density, and the percentage of available hard substrate (all p > 0.05) (Table S5 in the Supplement). The random effect variance for 'stone,' a dropstonelevel predictor accounting for over-dispersion (variability greater than expected for the Poisson distribution, i.e. a clumped dispersion pattern), was the greatest at 0.407 , suggesting that abundance varied greatly between dropstones due to unknown cause(s). Overall, the parameters in this model explained $38.5 \%$ of the variability in megafaunal abundance with $29.2 \%$ at- tributed to fixed effects. Similarly, dropstone area was a significant predictor of species richness $(p<0.001)$ and the random effect estimate for 'site' suggested no significant variation across sampling locations. Overall, parameters in the species-richness model captured $23.4 \%$ of the variation, with $21.8 \%$ of the variation attributed to fixed effects. A binomial GLMM was used to assess the relationship between presence/absence of any morphotype and dropstone parameters. In this model, both dropstone area and the percentage of dropstone area covered by sediment were significant predictors of presence $(p<0.01)$.

\section{Megafaunal community structure and diversity}

Bray-Curtis similarity and nMDS analyses revealed high transect-level variability in community structure and weak clustering at the fjord level. Generally, transects within fjords were $20-40 \%$ similar (Fig. 4), with some basins within Flandres Bay $<20 \%$ similar. There was no distinct separation between Barilari Bay and shelf samples. Because spatial clustering by 


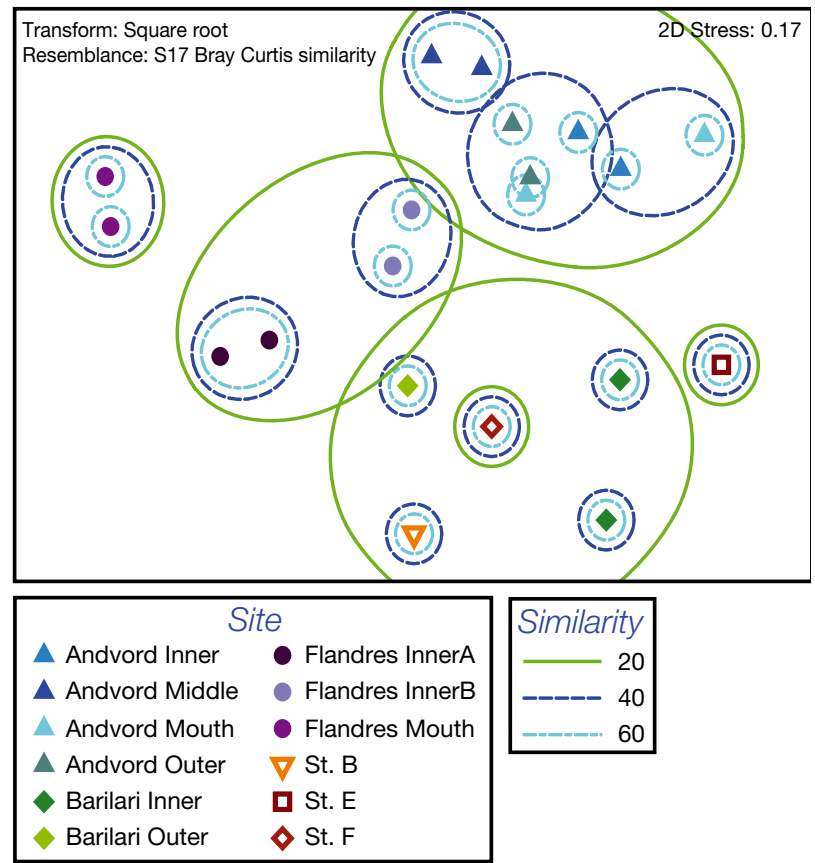

Fig. 4. Non-metric multidimensional scaling analysis from square-root transformed megafaunal abundances. Points represent communities at the transect level. Bray-Curtis similarity thresholds of 20,40 , and $60 \%$ are shown with colored lines. Station locations are given in Fig. 1

community composition was relatively weak, we explored how much of the variability could be attributed to abiotic factors using CAP. Individually, each abiotic factor could explain only $5.3-19.8 \%$ of the variability (Table $\mathrm{S} 6$ in the Supplement), but considered together, these parameters explained over $65 \%$ of the total variability in community composition. Dropstone density was most strongly correlated with the first axis of variation in community composition (Fig. 5). Several other environmental factors were moderately correlated with the first axis; these were bottom-water temperature, diatom primary production as estimated from silicic acid drawdown, and dropstone area. The second major axis of variation in this analysis can be attributed to differences in dropstone sediment cover. The percentage of available hard substrate (PercentHard) also correlated moderately with the second axis, but oppositely to dropstone sediment cover. The distribution of morphotypes in the CAP analysis (Fig. 6) revealed 2 groups, $\mathrm{A}$ and $\mathrm{B}$, which both included predatory/scavenging and suspension-feeding morphotypes. Morphotypes in group A were more positively correlated with silicic acid-derived production estimates and dropstone size, while those in group B were more positively correlated with temperature or dropstone sediment cover, although these appear to be weak associations. Morphotypes present in clusters A and B are summarized in Table 2.

Species accumulation curves show that fjord and shelf sites remain under-sampled since they do not reach an asymptote (Fig. 7, observed), precluding direct comparisons of total species richness. Instead, rarefaction estimates are calculated by randomly resampling the pool of samples while accounting for the increase of species richness with an increasing number of samples. Direct comparison of the species richness for a given number of sampled individuals is then possible. Rarefaction estimates of species richness (Es) for these data compared at the lowest number of individuals collected at the basin, site, and habitat levels $\left(\mathrm{Es}_{(11)}, \mathrm{Es}_{(12)}\right.$, and $\mathrm{Es}_{(116)}$, respectively) revealed that shelf locations exhibited higher rarefaction diversity than fjord locations. At the site level, Stn F, Flandres InnerA, and Andvord Outer had

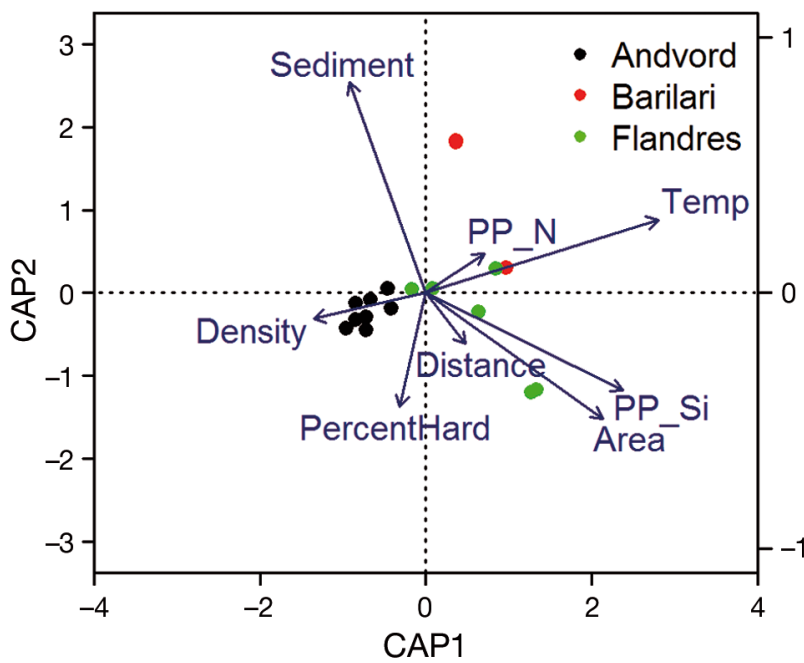

Fig. 5. Canonical analysis of principal coordinates (CAP) showing alignment of ordinated data (points colored by sampling site) with environmental predictors (vectors). CAP1 and CAP2 axes correspond to species data (points) whereas right-hand axis corresponds to correlations with environmental parameters (vectors). PP_Si and PP_N: mean productivity estimates based on silicic acid and nitrate drawdown, respectively, and summarized at the basin level; Sediment: sediment cover (\%) on dropstones summarized at the transect level; PercentHard: percentage of hard substrate available $\left(\mathrm{m}^{-2}\right)$ summarized at the transect level; Distance: distance from the nearest glacial terminus summarized at the basin level; Area: plan area of a dropstone summarized at the transect level; Density: abundance $\left(\mathrm{m}^{-2}\right)$ of dropstones summarized at the transect level; Temp: mean bottom water (>350 m) temperature measured in situ via CTD as close in space and time to phototransects as possible summarized at the basin level. Note that only data for fjord sampling locations are included. The length of the vector represents the strength of the correlation between that parameter and the community composition 


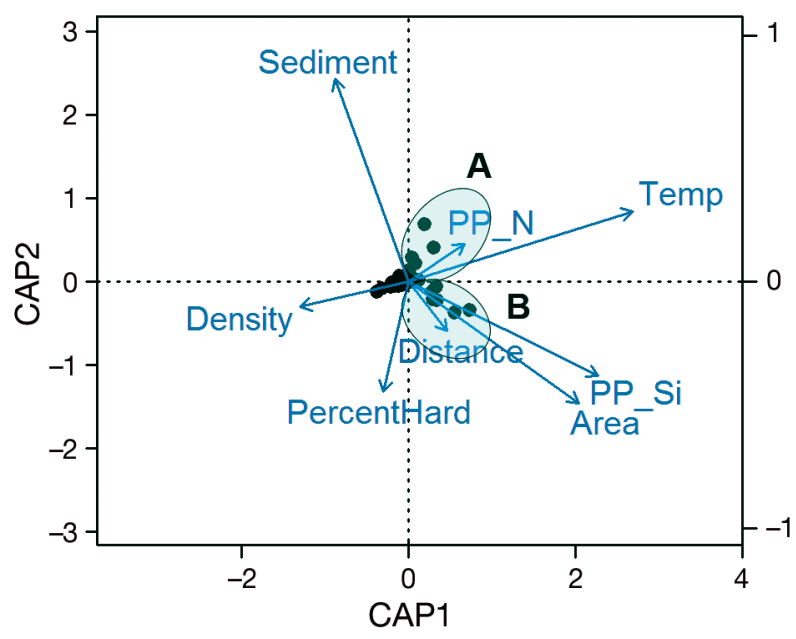

Fig. 6. Canonical analysis of principal coordinates (CAP) displaying ordinated megafaunal abundance data by morphotype (circles) correlated with environmental predictors (vectors). CAP1 and CAP2 axes correspond to species data (points) whereas right-hand axis corresponds to correlations with environmental parameters (vectors). Vector labels are as in Fig. 5. Morphotypes present in clusters A and B are provided in Table 2

the highest rarefaction diversity, due to both high evenness (Pielou's $J^{\prime}$ ) and species richness $(S)$ (Fig. S2 and Table S2). Flandres Outer and Andvord Middle stations had the lowest rarefaction diversity of all basins, again due to low evenness and richness (Table 3). Andvord Bay exhibited the lowest evenness overall of any site, likely due to a dominance of a single morphotype (Bryozoan sp. 5) present in very high abundances in the middle fjord which may have reduced overall diversity measures ( $H^{\prime}$ and Es) and may have contributed to reduced similarity to other regions within Andvord Bay (Table 3, Fig. 4). Shannon diversity estimates for these data indicate comparable diversity in both fjord and shelf habitats, but these estimates are sensitive to sample size (Magurran 2004) which was highly variable. Relatively high Shannon diversity was maintained even in the innermost regions of Andvord and Flandres Bays, where glacial disturbance was expected to be greatest. Using Chao 1, total species richness for pooled fjord and shelf phototransects was estimated to be $89( \pm 10)$ (Fig. 7). The fjord sites contributed most to the total estimated species richness (83 $\pm 14)_{i}$ however, the shelf remains undersampled, with Chao 1 suggesting there are approximately 27 additional species expected in this habitat.
Table 2. Morphotypes present in groups identified from CAP in Fig. 6. Feeding functional groups are PS: predator/ scavenger and SF: suspension feeder

\begin{tabular}{|ll|}
\hline Morphotype & Feeding group \\
\hline Group A & \\
Pycnogonida sp. 4 & PS \\
Cnemidocarpa verrucosa & SF \\
Bryozoan sp. 2 (Camptoplites sp.) & SF \\
Tunicate sp. 5 & SF \\
Bivalve sp. 2 & SF \\
Group B & \\
Amphipod sp. 1 Eusirid & PS \\
Prionosyllis kerguelensis & PS \\
Parborlasia corrugatus & PS \\
Demospongiae sp. 7 & SF \\
Porifera sp. 7 and sp. 2 & SF \\
\hline
\end{tabular}

\section{DISCUSSION}

\section{Island biogeography and species-area relationships}

Dropstones constitute a small fraction $(<1 \%)$ of the seafloor in this region, and their patchy distribution reflects a heterogeneous delivery mechanism which creates a mosaic of isolated hard-substrate habitat patches. The community patterns observed in this study mirror those of classic island communities, conforming to predictions of island biogeography theory. The correlations between dropstone area and species richness and abundance, and the increase in the proportion of dropstones colonized with increasing dropstone size, match the predicted island-versus-size relationships of island biogeog-

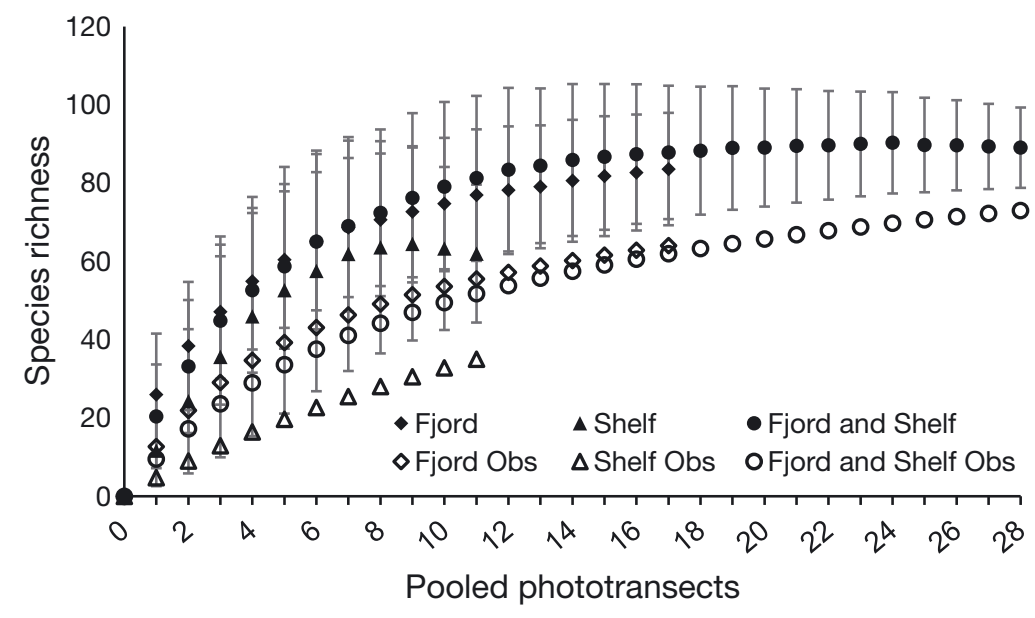

Fig. 7. Chao 1 species richness estimates $( \pm \mathrm{SD})$ and observed species richness (species accumulation) for fjord and shelf phototransects combined (solid and open circles), fjord phototransects only (solid and open diamonds), and for shelf phototransects (solid and open triangles) 
Table 3. Summary of diversity indices. $S$ : total richness, $J^{\prime}$ : Pielou's evenness, $\mathrm{Es}_{(\mathrm{min})}$ : rarefaction, $H^{\prime}$ : Shannon-Weiner diversity index. Rarefaction estimates were assessed at the minimum number of individuals for the level of comparison (Es $\mathbf{s}_{(11)}$ for basin-level comparisons, $\mathbf{E s}_{(12)}$ for site-level comparisons, and $\mathrm{Es}_{(116)}$ for habitat-level comparisons). The number of individuals, $\mathrm{n}$, sampled for each site at these various levels of comparison is provided for reference

\begin{tabular}{|lccccccc|}
\hline & $S$ & $\mathrm{n}$ & $J^{\prime}$ & $\mathrm{Es}_{(11)}$ & $\mathrm{Es}_{(12)}$ & $\mathrm{Es}_{(116)}$ & $H^{\prime}$ \\
\hline Fjord & 64 & 1650 & 0.5977 & - & - & 28.13 & 2.486 \\
Andvord Bay & 40 & 1170 & 0.4439 & - & 4.53 & - & 1.637 \\
Inner & 17 & 75 & 0.8248 & 6.771 & - & - & 2.337 \\
Middle & 27 & 954 & 0.6543 & 3.468 & - & - & 1.238 \\
Outer & 20 & 70 & 0.8968 & 7.934 & - & - & 2.687 \\
Mouth & 18 & 71 & 0.6543 & 5.395 & - & - & 1.891 \\
Flandres Bay & 47 & 440 & 0.7557 & - & 8.076 & - & 2.91 \\
Inner A & 16 & 264 & 0.9028 & 7.259 & - & - & 2.751 \\
Inner B & 38 & 132 & 0.9456 & 4.671 & - & - & 1.701 \\
Outer & 6 & 44 & 0.9076 & 3.758 & - & - & 1.173 \\
Barilari Bay & 12 & 40 & 0.7327 & - & 5.759 & - & 1.821 \\
Inner & 8 & 29 & 0.9277 & 4.653 & - & - & 1.51 \\
Outer & 7 & 11 & 0.98 & 7 & - & - & 1.768 \\
Shelf & 35 & 116 & 0.8661 & - & - & 35 & 3.079 \\
Stn B & 7 & 12 & 0.873 & - & 7 & - & 1.699 \\
Stn E & 8 & 20 & 0.922 & - & 6.536 & - & 1.917 \\
Stn F & 25 & 84 & 0.8661 & - & 8.496 & - & 2.788 \\
\hline
\end{tabular}

walls), which is expected for island habitats. This is consistent (albeit weakly) with the findings of Meyer et al. (2016) for Arctic dropstone communities, in which dispersal-limitation caused by increasing distance from a large, hardsubstrate larval source (i.e. a 'mainland') explained most of the variability in the communities (Meyer et al. 2016). Dropstones within WAP fjords likely have a residence time of years because the sedimentation rate in the fjords is $\sim 0.5-1 \mathrm{~cm} \mathrm{yr}^{-1}$, while dropstones on the outer shelf likely remain exposed for decades because the sedimentation rate is 2 orders of magnitude lower $(\sim 0.02 \mathrm{~cm}$ $\mathrm{yr}^{-1}$; Grange \& Smith 2013). Increasing exposure time increases the probability that a dropstone will be colonized, at a given rate of colonization. Because occupancy rates of dropstones in the fjords and on the shelf appear comparable for a given size class of dropstone, colonization rates are likely substantially lower

raphy. Recent investigations of Arctic dropstone communities in Svalbard yielded similar relationships between dropstone size and species richness (Meyer et al. 2016). It is clear from our study that dropstone communities in fjords along the WAP and on the open Antarctic shelf were not spacelimited; all dropstones contained open space, and uncolonized stones often were covered with sediment, indicating they had been at the seafloor for a relatively long time. In addition, we found a weak, positive relationship between colonization and dropstone sediment cover, and the binomial model indicates that dropstone sediment cover is a significant predictor of colonization $(\mathrm{p}<0.05)$; this suggests that longer exposure time increases the chances of colonization, a pattern consistent with recruitment limitation. Thus, on WAP dropstones, community composition and species richness is controlled, at least in part, by the arrival of colonists rather than by density-dependent processes (e.g. competition) within 'island' assemblages, as originally postulated in island biogeography theory. The insignificance of dropstone density as a predictor of either species richness or megafaunal abundance does not support an effect of distance between individual dropstones. Improved fit of the mixed models with the inclusion of sampling site suggests, instead, differences between sites in the distance to large source populations (e.g. fjord on the open shelf. Future colonization studies are needed to constrain the rates of colonization and other processes on dropstones, including post-settlement dynamics, such as competition and mortality, as well as the residence time (time to burial) of dropstone substrates.

In addition to island biogeography theory, models explicitly relating sample area, or oceanic island size, to species richness have been developed (e.g. McGuinness 1984, Durrett \& Levin 1996, He \& Legendre 1996, Scheiner 2003, Tjørve 2003, Smith 2010). The power model, $S=C A^{z}$, is most commonly applied (He \& Legendre 1996, Scheiner 2003). In this equation, $S$ is the species richness for an island of area $A$, and $c$ and $z$ are constants, with island communities tending to yield an exponent, $z$, of approximately 0.2-0.3 (Durrett \& Levin 1996, Rosenzweig 2003). Our dropstone data set can be modeled with an exponent of $0.208-0.311$, consistent with power models fitted to island habitats and other speciesarea studies worldwide.

\section{Drivers of small-scale community structure patterns}

Patterns of dropstone community similarity varied at scales ranging from the individual dropstone to 100s of kilometers along the WAP. In contrast to the soft-sediment megafauna (Grange \& Smith 2013), the 
dropstone community composition did not cluster tightly by fjord, with nMDS clusters for Barilari Bay and the open shelf stations substantially overlapping. The dropstone community appears to be more similar across fjord and shelf habitats than the soft-sediment megafauna. The relatively strong clustering of Andvord Bay dropstone samples may be driven by the extremely high abundances of a single morphotype, Bryozoan sp. 5, which was far less abundant at the other sampling locations. The presence of uncolonized dropstones may simply reflect more recent deposition and not a lack of substrate utilization since it can be advantageous for suspension-feeding fauna to settle higher in the benthic boundary layer where the flux of suspended particles is higher (Vogel 1981, Mullineaux 1988, Schulz et al. 2010). At the withinfjord scale, diversity did not decrease with decreasing distance to the glacial front as expected from comparison with northern hemisphere high-latitude fjords; this finding is consistent with soft-sedimentcommunity patterns in the WAP (Grange \& Smith 2013), in which megabenthic diversity remained high within a few kilometers of glacial termini. It was postulated that relatively low disturbance from meltwater and sediment plumes in WAP fjords allows the maintenance of such high abundance and diversity within soft-sediment megafaunal assemblages (Grange \& Smith 2013). This hypothesis also appears viable for dropstone megafauna, i.e. fjord sedimentation rates are low enough to allow colonization of dropstones even in the inner basins of the fjords where strong burial disturbance is expected. The megafaunal communities studied here are below the depth of iceberg scour and appear to be free of anchor-ice formation; they thus may experience lower rates of other types of physical disturbance than at shallow depths along the Antarctic shelf (Barnes \& Conlan 2007, Smale \& Barnes 2008).

\section{Drivers of large-scale community structure patterns}

At larger scales of 100 s of kilometers, bottomwater temperature (a proxy for water mass identity and potential larval sources) became an important factor in differentiating communities among our study sites. Bottom water temperatures between Andvord Bay and Flandres Bay, for example, differ by $>1{ }^{\circ} \mathrm{C}$ even though they are neighboring fjords, and Flandres Bay more closely resembled open shelf waters along the southern WAP that are influenced by warm, upper circumpolar deep water (UCDW) (Hofmann et al. 1996, Smith et al. 1999,
Savidge \& Amft 2009, Piñones et al. 2011, Cook et al. 2016). Recent studies provide little evidence of modified UCDW inside Andvord Bay (Ø. Lundesgaard and P. Winsor pers. comm.), while this water mass does occur in Flandres Bay southward along the WAP (Cook et al. 2016), suggesting that the adjacent fjords, Andvord and Flandres Bays (Fig. 1) may have different water mass sources and experience less exchange than might be expected based on their proximity. In general, circulation in Andvord Bay is weak, decoupled from processes on the open shelf $(\varnothing$. Lundesgaard and P. Winsor pers. comm.). This could contribute to poor connectivity between fjords as well as between fjord and shelf sites, leading to community differences on scales of 10-100 km. Similar results were observed in the Arctic as well, where variability in functional traits of dropstone fauna was best correlated with bottomwater temperature (Meyer et al. 2015).

In addition to bottom-water temperature, the mean dropstone size, sediment cover, and annual overlying primary production were best correlated with benthic megafaunal community composition. Overlying production constrains the flux of organic carbon to the seafloor, especially along the WAP where export ratios can be high (Smith et al. 2008, Buesseler et al. 2010). Interestingly, annual production estimated via nitrate uptake was more weakly correlated with benthic community composition than production estimated from silicic acid uptake, which represents only the production due to diatoms. These results suggest that mobile, predatory/ scavenging megafauna may be more abundant in areas where episodic delivery of phytodetritus from large diatom blooms is prevalent. This response is likely indirect as predators may respond to an aggregation or enhanced activity of surface depositfeeding megafauna that respond quickly to phytodetrital inputs (Sumida et al. 2008, 2014). The correlation of large poriferan (suspension-feeders) abundance with diatom production may reflect their ability to cope with variable and highly seasonal food availability by utilizing different food sources, especially when productivity is episodic (e.g. Thurber 2007). The smaller tunicate and bryozoan morphotypes were correlated with production estimated by nitrate drawdown and oppositely correlated with dropstone sediment cover. This suggests the need for dropstones and a reliance on a consistent food source. These organisms are likely more successful in areas of high and less variable total production (i.e. fewer large diatom blooms) and low dropstone sediment cover. 


\section{Ecosystem function of dropstones}

Glacial dropstones on the WAP contribute disproportionately on an area basis to the overall gamma diversity of the WAP fjord-shelf system at 400-700 m by providing $\sim 1 \%$ of the seafloor habitat space but contributing $20 \%$ of the regional soft and hard substrate species pool. Comparison with a soft-sediment megafaunal survey of this region (Grange \& Smith 2013) revealed 44 overlapping morphotypes and an additional 29 morphotypes that were previously not recorded, 22 of which were hard-substrate obligates. While dropstones support colonization by obligate hard-substrate fauna, they also support ecological functions for mobile megafauna. In particular, a demersal fish (Chaenodraco wilsoni) was observed numerous times guarding egg masses attached to the tops of dropstones (Kock et al. 2008), and a benthic medusa (Ptychogastria polaris) was also seen adhered to dropstones (Fig. 8). While C. wilsoni deposits eggs on dropstones, other benthic notothenoids, such as Chaenocephalus aceratus, have been observed guarding gravel nests in the northern Ant- arctic Peninsula region (Detrich et al. 2005, Reid et al. 2007). Enhanced burial of this substrate, by increased sedimentation due to climate warming and glacial melt or other mechanisms, could reduce the extent of nursery grounds of these benthic fishes as well as the habitat space for obligate fauna. Although increased melting could also lead to higher rates of calving, iceberg production and, therefore, dropstone deposition rate, there is no evidence to suggest the total amount of hard substrate would increase. Given the importance of dropstones as a habitat for obligate hard substrate fauna and even mobile fauna in these fjord and shelf ecosystems, the ecological role of dropstones merits study in other parts of the Southern Ocean and in polar regions generally.

\section{CONCLUSIONS}

Glacial dropstones in high-latitude fjord and shelf ecosystems provide heterogeneity and enhance WAP regional species richness at 400-700 $\mathrm{m}$ depths by
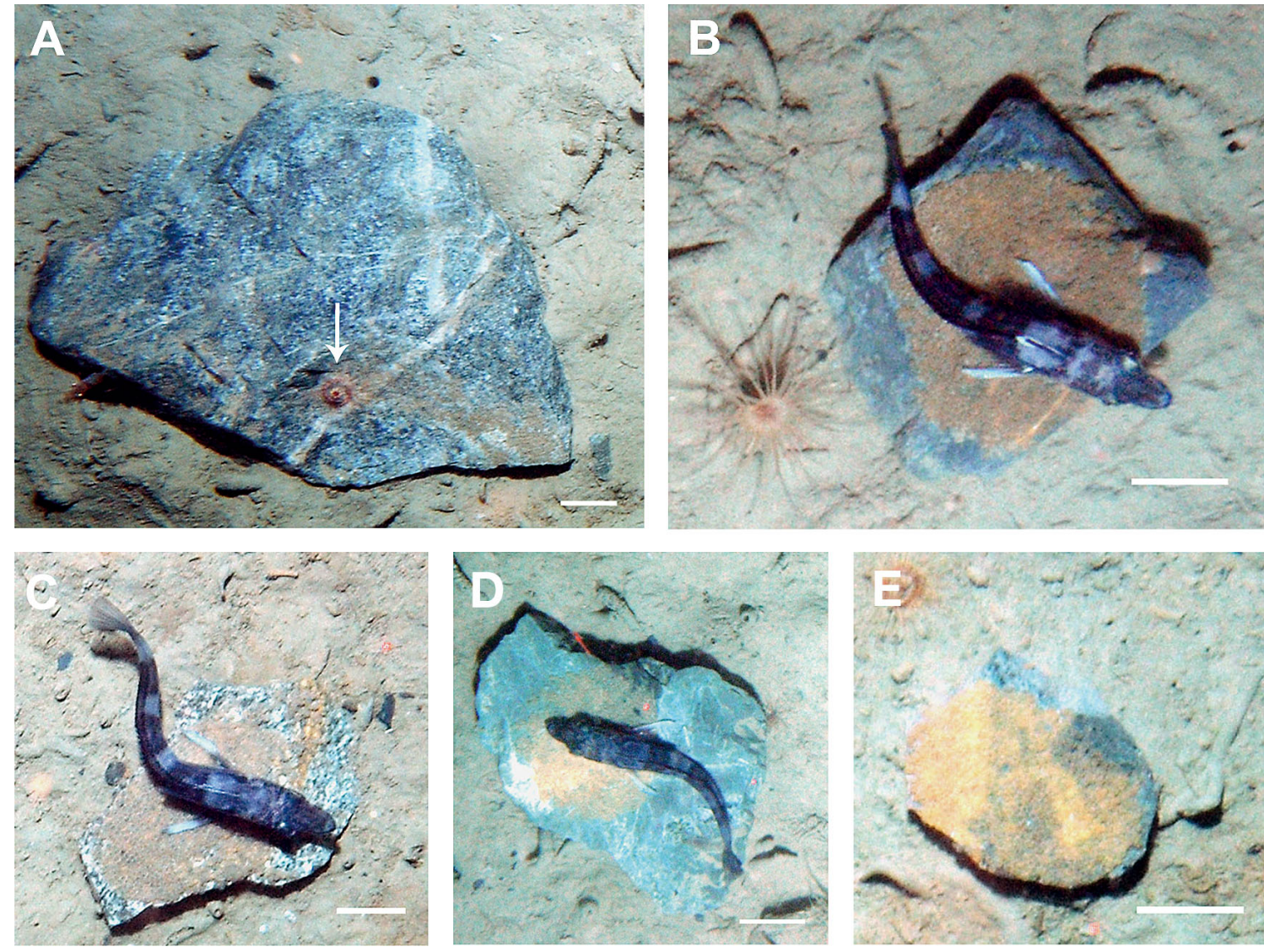

Fig. 8. Examples of (A) Ptychogastria polaris (arrow), (B,C,D) Chaenodraco wilsoni guarding egg masses on dropstones, and

(E) C. wilsoni egg mass on dropstone. All scale bars $=5 \mathrm{~cm}$ 
$20 \%$. Dropstones appear to function as island habitats in these ecosystems by adhering to principles of island biogeography theory. Dropstone megafaunal abundance and diversity in Andvord, Barilari, and Flandres Bays were most highly correlated with mean dropstone size, bottom-water temperature, overlying annual primary production, and dropstone sediment cover. The 3 feeding modes of megafauna observed in this study were correlated differently with environmental parameters, but this could not explain large proportions of variability in the community composition. Rather, it appears a combination of island-like assembly processes and influences from the abiotic environment have shaped these benthic communities. Dropstone community structure in both the Antarctic and Arctic ecosystems appear to be mainly influenced by disperal and recruitment limitation. The use of dropstones as egg-brooding sites by the benthic fish Chaenodraco wilsoni indicates that both sessile (hard-substrate obligate) and mobile components of fjord megabenthos may be negatively impacted if warming increases fjord sedimentation rates and dropstone burial in the future.

Acknowledgements. Funding was provided by National Science Foundation grants for the LARISSA (OPP 0732711), FOODBANCS2 (OPP 0636806), and FjordEco (OPP 1443 680) projects to C.R.S. We thank the captains and crews of the AVIB 'Nathaniel B. Palmer' and ASRV 'Laurence M. Gould' as well as the numerous United States Antarctic Program (USAP) personnel and scientists who assisted in the field. We also thank Thomas Desvignes (Oregon State University) for fish identifications and Dr. Laura Grange and Christian Clark for their help in the field and processing of the original benthic imagery.

\section{LITERATURE CITED}

Amon DJ, Ziegler AF, Dahlgren TG, Glover AG and others (2016) Insights into the abundance and diversity of abyssal megafauna in a polymetallic-nodule region in the eastern Clarion-Clipperton Zone. Sci Rep 6:30492

Barnes DK, Conlan KE (2007) Disturbance, colonization and development of Antarctic benthic communities. Philos Trans R Soc Lond B Biol Sci 362:11-38

Bates D, Mächler M, Bolker B, Walker S (2015) Fitting linear mixed-effects models using lme4. J Stat Softw 67:1-46

Bennett MR, Doyle P, Mather AE (1996) Dropstones: their origin and significance. Palaeogeogr Palaeoclimatol Palaeoecol 121:331-339

Boldt KV, Nittrouer CA, Hallet B, Koppes MN, Forrest BK, Wellner JS, Anderson JB (2013) Modern rates of glacial sediment accumulation along a $15^{\circ} \mathrm{S}-\mathrm{N}$ transect in fjords from the Antarctic Peninsula to southern Chile. J Geophys Res Earth Surf 118:2072-2088

Brueggeman P (1998) Underwater field guide to Ross Island \& McMurdo Sound, Antarctica. www.peterbrueggeman. com/nsf/fguide/
Buesseler KO, McDonnell AMP, Schofield OME, Steinberg DK, Ducklow HW (2010) High particle export over the continental shelf of the west Antarctic Peninsula. Geophys Res Lett 37:L22606

Cook AJ, Fox AJ, Vaughan DG, Ferrigno JG (2005) Retreating glacier fronts on the Antarctic Peninsula over the past half-century. Science 308:541-544

Cook AJ, Holland PR, Meredith MP, Murray T, Luckman A, Vaughan DG (2016) Ocean forcing of glacier retreat in the western Antarctic Peninsula. Science 353: 283-286

Cummings V, Thrush S, Norkko A, Andrew A, Hewitt J, Funnell G, Schwarz AM (2006) Accounting for local scale variability in benthos: implications for future assessments of latitudinal trends in the coastal Ross Sea. Antarct Sci 18:633-644

* Detrich HW III, Jones CD, Kim S, North AW, Thurber A, Vacchi M (2005) Nesting behavior of the icefish Chaenocephalus aceratus at Bouvetøya Island, Southern Ocean. Polar Biol 28:828-832

* Domack EW, Ishman S (1993) Oceanographic and physiographic controls on modern sedimentation within Antarctic fjords. Geol Soc Am Bull 105:1175-1189

Domack EW, McClennen CE (1996) Accumulation of glacial marine sediments in fjords of the Antarctic Peninsula and their use as late Holocene paleoenvironmental indicators. Antarct Res Ser 70:135-154

* Durrett R, Levin S (1996) Spatial models for species area curves. J Theor Biol 179:119-127

*Elverhoi A, Seland R (1983) Glaciomarine sedimentation in a modern fjord environment, Spitsbergen. Polar Res 1: $127-149$

Grange LJ, Smith CR (2013) Megafaunal communities in rapidly warming fjords along the West Antarctic Peninsula: hotspots of abundance and beta diversity. PLOS ONE 8:e77917

* Gutt J (2001) On the direct impact of ice on marine benthic communities, a review. Polar Biol 24:553-564

Gutt J, Piepenburg D (2003) Scale-dependent impact on diversity of Antarctic benthos caused by grounding of icebergs. Mar Ecol Prog Ser 253:77-83

* He F, Legendre P (1996) On species-area relations. Am Nat 148:719-737

Kofmann EE, Klinck JM, Lascara CM, Smith DA (1996) Water mass distribution and circulation west of the Antarctic Peninsula and including Bransfield Strait. In: Ross RM, Hofmann EE, Quetin LB (eds) Foundations for ecological research west of the Antarctic Peninsula. American Geophysical Union, Washington, DC, p 61-80

Huston M (1979) A general hypothesis of species diversity. Am Nat 113:81-101

Kock KH, Pshenichnov L, Jones CD, Gröger J, Riehl R (2008) The biology of the spiny icefish Chaenodraco wilsoni Regan, 1914. Polar Biol 31:381-393

*Lacharité M, Metaxas A (2017) Hard substrate in the deep ocean: how sediment features influence epibenthic megafauna on the eastern Canadian margin. Deep Sea Res I 126:50-61

MacArthur RH, Wilson EO (1967) The theory of island biogeography. Princeton University Press, Princeton, NJ

Magurran AE (2004) Measuring biological diversity. Blackwell Publishing, Oxford

McClintock JB, Amsler CD, Baker BJ, van Soest RWM (2005) Ecology of Antarctic marine sponges: an overview. Integr Comp Biol 45:359-368 
McGuinness KA (1984) Species-area curves. Biol Rev Camb Philos Soc 59:423-440

Meredith MP (2005) Rapid climate change in the ocean west of the Antarctic Peninsula during the second half of the 20th century. Geophys Res Lett 32:L19604

Meyer KS, Sweetman AK, Young CM, Renaud PE (2015) Environmental factors structuring Arctic megabenthos a case study from a shelf and two fjords. Front Mar Sci 2: 22

Meyer KS, Young CM, Sweetman AK, Taylor J, Soltwedel T, Bergmann M (2016) Rocky islands in a sea of mud: biotic and abiotic factors structuring deep-sea dropstone communities. Mar Ecol Prog Ser 556:45-57

Mullineaux LS (1988) The role of settlement in structuring a hard-substratum community in the deep sea. J Exp Mar Biol Ecol 120:247-261

Oksanen J, Blanchet FG, Friendly M, Kindt R and others (2017) vegan: community ecology package. https://cran. r-project.org/package=vegan

Oschmann W (1990) Dropstones-rocky mini-islands in high-latitude pelagic soft substrate environments. Senckenb Marit 21:55-75

Piñones A, Hofmann EE, Dinniman MS, Klinck JM (2011) Lagrangian simulation of transport pathways and residence times along the western Antarctic Peninsula. Deep Sea Res II 58:1524-1539

Post AL, Lavoie C, Domack EW, Leventer A, Shevenell A, Fraser AD, NBP 14-02 Science Team (2017) Environmental drivers of benthic communities and habitat heterogeneity on an East Antarctic shelf. Antarct Sci 29:17-32

Pritchard HD, Vaughan DG (2007) Widespread acceleration of tidewater glaciers on the Antarctic Peninsula. J Geophys Res 112(F3):F03S29

Reid WDK, Clarke S, Collins MA, Belchier M (2007) Distribution and ecology of Chaenocephalus aceratus (Channichthyidae) around South Georgia and Shag Rocks (Southern Ocean). Polar Biol 30:1523-1533

Rosenzweig ML (1995) Species diversity in space and time. Cambridge University Press, Cambridge

Rosenzweig ML (2003) Reconciliation ecology and the future of species diversity. Oryx 37:194-205

Savidge DK, Amft JA (2009) Circulation on the West Antarctic Peninsula derived from 6 years of shipboard ADCP transects. Deep Sea Res I 56:1633-1655

Scheiner SM (2003) Six types of species-area curves. Glob Ecol Biogeogr 12:441-447

Schönberg CHL, Fromont J (2012) Sponge gardens of Ningaloo Reef (Carnarvon Shelf, Western Australia) are biodiversity hotspots. Hydrobiologia 687:143-161

Schulz M, Bergmann M, von Juterzenka K, Soltwedel T (2010) Colonisation of hard substrata along a channel system in the deep Greenland Sea. Polar Biol 33: 1359-1369

Simberloff DS (1974) Equilibrium theory of island biogeography and ecology. Annu Rev Ecol Evol Syst 5:161-182

Smale DA, Barnes DKA (2008) Likely responses of the Antarctic benthos to climate-related changes in physical disturbance during the 21st century, based primarily on evidence from the West Antarctic Peninsula region. Ecography 31:289-305

Editorial responsibility: James McClintock, Birmingham, Alabama, USA
Smith AB (2010) Caution with curves: caveats for using the species-area relationship in conservation. Biol Conserv 143:555-564

* Smith CR, Mincks S, DeMaster DJ (2006) A synthesis of bentho-pelagic coupling on the Antarctic shelf: food banks, ecosystem inertia and global climate change. Deep Sea Res II 53:875-894

Smith CR, Mincks S, DeMaster DJ (2008) The FOODBANCS project: introduction and sinking fluxes of organic carbon, chlorophyll-a and phytodetritus on the western Antarctic Peninsula continental shelf. Deep Sea Res II 55: 2404-2414

Smith CR, DeMaster DJ, Thomas CJ, Sršen P, Grange L, Evrard V, DeLeo F (2012) Pelagic-benthic coupling, food banks, and climate change on the West Antarctic Peninsula shelf. Oceanography 25:188-201

Smith DA, Hofmann EE, Klinck JM, Lascara CM (1999) Hydrography and circulation of the West Antarctic Peninsula Continental Shelf. Deep Sea Res I 46:925-949

Starmans A, Gutt J, Arntz WE (1999) Mega-epibenthic communities in Arctic and Antarctic shelf areas. Mar Biol 135:269-280

Sumida PYG, Bernardino AF, Stedall VP, Glover AG, Smith CR (2008) Temporal changes in benthic megafaunal abundance and composition across the West Antarctic Peninsula shelf: results from video surveys. Deep Sea Res II 55:2465-2477

Sumida PYG, Smith CR, Bernardino AF, Polito PS, Vieira DR (2014) Seasonal dynamics of epibenthic megafauna on the deep West Antarctic Peninsula in response to variable phytodetrital influx. R Soc Open Sci 1:140294

* Sutherland DA, Roth GE, Hamilton GS, Mernild SH, Stearns LA, Straneo F (2014) Quantifying flow regimes in a Greenland glacial fjord using iceberg drifters. Geophys Res Lett 41:8411-8420

* Syvitski JPM, Andrews JT, Dowdeswell JA (1996) Sediment deposition in an iceberg-dominated glacimarine environment, East Greenland: basin fill implications. Global Planet Change 12:251-270

* Thrush SF, Hewitt JE, Cummings VJ, Norkko A, Chiantore $M$ (2010) Beta-diversity and species accumulation in Antarctic coastal benthos: influence of habitat, distance and productivity on ecological connectivity. PLOS ONE 5:e11899

Thurber AR (2007) Diets of Antarctic sponges: links between the pelagic microbial loop and benthic metazoan food web. Mar Ecol Prog Ser 351:77-89

Tjørve E (2003) Shapes and functions of species area curves: a review of possible models. J Biogeogr 30:827-835

*Vaughan DG, Marshall GJ, Connolley WM, King JC, Mulvaney R (2001) Devil in the detail. Science 293: 1777-1779

Vogel S (1981) Life in moving fluids: the physical biology of flow. Princeton University Press, Princeton, NJ

Wentworth CK (1922) A scale of grade and class terms for clastic sediments. J Geol 30:377-392

Wlodarska-Kowalczuk M, Pearson TH, Kendall MA (2005) Benthic response to chronic natural physical disturbance by glacial sedimentation in an Arctic fjord. Mar Ecol Prog Ser 303:31-41

Submitted: July 6, 2017; Accepted: October 9, 2017

Proofs received from author(s): November 11, 2017 